Espaço Aberto | Open Space

\title{
Arte - antropologia - arte: sobre as capas da revista Horizontes Antropológicos
}

Art - anthropology - art: the covers of the Horizontes Antropológicos magazine

\author{
Paula Ramos ${ }^{*}$ \\ *Universidade Federal do Rio Grande do Sul - Porto Alegre, RS, Brasil \\ paulavivianeramos@gmail.com
}




\title{
Resumo
}

De suvenir de museu a mote de releituras, o universo da história da arte tem atendido a distintos propósitos extra-artísticos. Cineastas, designers e, em especial, profissionais da área da comunicação referenciam-no constantemente, levando para campanhas publicitárias, cartazes e identidades visuais, entre outros produtos, fragmentos e alusões a esse campo. O mesmo se verifica, com frequência, nas capas da revista Horizontes Antropológicos. A partir de uma reflexão acerca dos usos das imagens artísticas pela comunicação e tomando como escopo cinco edições do periódico, o artigo perscruta as obras adotadas, enfatizando aspectos como representação e simbologia, funções sociais e trajetória. Do diálogo sintético e temático entre arte e antropologia, proposto pelos editores, vai-se a um diálogo analítico, que explicita o valor histórico desse patrimônio, tendo como base o seu valor primordial, artístico. No alinhavo entre as obras e na abordagem das mesmas, ressalta-se a construção, pelos artistas, de suas próprias imagens, como agentes de transformação social.

Palavras-chave: arte e comunicação; arte e antropologia; autorrepresentação; Horizontes Antropológicos.

\begin{abstract}
From museum souvenirs to the focus of re-readings, the universe of art history has been used for different extra-artistic purposes. Constantly, filmmakers, designers and, in particular, professionals in the area of communication refer to it, taking fragments and allusions from this field to publicity campaigns, posters, visual identities, among others. This process can be frequently seen on the covers of Horizontes Antropologi$\cos$. Based on a reflection about the use of artistic images by the communication area and having as scope five specific issues of the magazine, this article investigates the artworks chosen, emphasizing some aspects such as representation and symbology, social function and trajectory. From a synthetic and thematic dialogue between art and anthropology, proposed by the editors of the magazine, an analytical dialogue emerges and justifies the historical value of this patrimony, taking into account its primordial value: the artistic one. From the artworks outline and approach, the construction by the artists of their own images can be emphasized, showing their role as social transformation agents.
\end{abstract}

Keywords: art and communication; art and anthropology; self-representation; Horizontes Antropológicos. 
Uma obra de arte deveria sempre nos ensinar que não tínhamos visto o que vemos.

Paul Valéry

\section{Às avessas}

Um dos mais festejados nomes da história da arte, Vincent van Gogh (1853-1890) não gozou de reconhecimento em vida: participou de raros eventos, vendeu um único quadro e era visto, inclusive por muitos de seus pares, como esquisito e temperamental. Tinha cerca de 30 anos quando resolveu ser pintor e, então, de modo vigoroso e admirável, voltou-se ao ofício, produzindo mais de duas mil obras. Sua poética transformou para sempre a pintura, sobretudo os gêneros da paisagem e do retrato. Produtivo, intenso e ousado, Van Gogh tinha crises de transtorno bipolar e epilepsia, oscilando entre entusiasmo e desolação. E, embora seus biógrafos e comentaristas o definam como um homem que procurava a companhia de outras pessoas, era com frequência ignorado, sofrendo de solidão, tristeza, incompreensão. O exílio o angustiava, as tempestades psíquicas o assombravam, a carência de dinheiro se mantinha, mas ele não esmorecia, trabalhando febrilmente e contando com o apoio afetivo e financeiro do irmão Theo. No verão europeu de 1890, Van Gogh finalizou a tela Trigal com corvos, junto a uma planície em Auvers-sur-Oise, onde vivia, a noroeste de Paris. Voltou ali a 27 de julho e disparou uma arma de fogo contra si mesmo, falecendo dois dias depois.

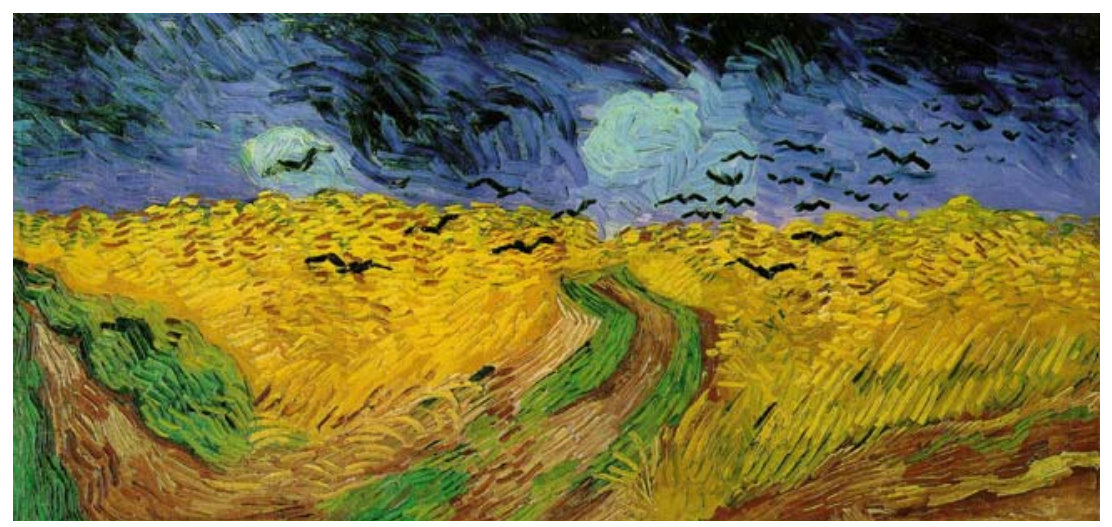

Figura 1. Vincent van Gogh (1853-1890), Trigal com corvos, 1890, óleo sobre tela, 50,2 × $103 \mathrm{~cm}$, Van Gogh Museum, Amsterdam, Holanda. 
Durante anos, a reprodução de Trigal com corvos, junto com outras imagens do artista, foi usada na decoração de salas destinadas aos "clientes VIP" de uma rede bancária com sede na Holanda e também atuante no Brasil. Adotando a divisa "arte em relacionamento", a empresa anunciava pautar-se na cumplicidade e na confiança entre os irmãos Vincent e Theo; por meio do serviço, calcado em exclusivos gerentes de conta e na nova ambientação, buscava "o que todo artista precisa para fazer uma grande obra": talento, instrumentos, espaço e paixão. No País, o controle acionário dessa multinacional passou a outros administradores, mas a diretriz permanece, oferecendo aos "clientes Van Gogh", com alta renda e saldo bancário disponível para aplicações financeiras, gentilezas que vão do cafezinho e presentes de final de ano à isenção de tarifas.

Sempre me perguntei como os dirigentes e os publicitários que desenvolveram esse conceito chegaram a algo tão frágil e questionável. Muitos poderão dizer que se trata de uma justa homenagem da instituição holandesa ao conterrâneo, reverenciando seu gênio e singularidade. Outros poderão arguir que o impacto determinante da campanha está no vínculo de distinção, uma vez que os clientes abastados querem ter suas imagens associadas a personagens e a produtos reconhecidos por seu requinte e alto valor econômico e, sendo assim, a maestria de Van Gogh suplanta o funesto por trás de sua história pessoal e, especialmente, por trás de Trigal com corvos. ${ }^{1}$ No rol dos argumentos, haverá os que levantarão a bandeira do aconchego evocado pelos amarelos vibrantes das pinturas do mestre, ainda mais em recintos bancários, quase sempre frios, impessoais e monótonos.

As possibilidades de escrutínio são vastas, mas uma derivação, pela tangente, reforça o mal-estar: se imaginarmos Vincent van Gogh se dirigindo a esse mesmo banco e submetendo seus dados ao cadastro e à análise, é fácil inferir que ele jamais seria aceito como correntista. Não apenas isso, o que qualifica o serviço "Van Gogh" é o seu caráter "receptivo e amigável", algo que o artista buscou durante toda a sua vida, com pouco sucesso. Embaraçoso, esse case de marketing às avessas sugere muitas coisas: imperícia, banalidade, ironia.

1 O crítico de arte inglês John Berger (1999), em seu livro Modos de ver, chama a atenção para o fato de que é difícil apreender em que medida a informação "esta foi a última pintura feita por Vincent van Goh antes de se matar" transforma a imagem; mas, ele assevera, tal dado indubitavelmente o faz. 


\section{Sem qualquer constrangimento}

De suvenir de museu a mote de releituras, o universo da história da arte tem atendido a distintos propósitos extra-artísticos. Cineastas, designers e, em especial, profissionais da comunicação referenciam-no constantemente, levando para campanhas publicitárias, capas de livros, cartazes e identidades visuais, entre outros produtos, fragmentos e alusões a esse campo. A motivação para tal uso quase sempre reside na valoração simbólica, ou seja, na associação do que se está produzindo ou divulgando com algo já consagrado pela tradição. Mas pode passar por uma simples função "ilustrativa", no seu sentido mais prosaico e corriqueiro, do tipo: “Uma imagem que caracterize o Renascimento? Que tal... a Mona Lisa?"

Mona Lisa ou A Gioconda (1503-1506) é, certamente, a obra de arte mais popular do mundo. ${ }^{2}$ Diante dela, amontoam-se centenas de visitantes todos os dias, registrando em selfies a visita obrigatória de todo turista em Paris: o Louvre. É difícil acreditar que as fotografias à exaustão possam atestar alguma empatia ou comunhão com a obra, ou mesmo com a figura de seu criador, Leonardo da Vinci (14521519). Fácil, porém, é relacionar o assédio permanente e eufórico à mensagem "ei, estou aqui, diante dela!", ou, ainda, "ei, estou aqui, em Paris!" - afinal, pela lógica narcísica que rege a contemporaneidade, não basta "estar em um lugar", é preciso "comprová-lo" e, preferencialmente, fazê-lo numa plataforma de rede social.

Personagem "pop" por excelência, a Mona Lisa empresta seu rosto, pose, olhar e sorriso para vender alimentos, amaciantes de roupas, absorventes íntimos, viagens internacionais e, claro, produtos para tratamento de cabelos. Rainha dos "memes", ela protagoniza encenações infindáveis, revelando o dote de seus autores no uso de softwares de edição de imagens. É quando desponta com olhos arregalados, cara de choro, bigode, braços de estivador, comentando

2 A pintura, um óleo sobre madeira de álamo, com $77 \times 53 \mathrm{~cm}$, representa Lisa di Gherardo, esposa de Francesco del Giocondo - daí, inclusive, os dois nomes pelos quais é conhecida. No século $\mathrm{XV}$, os retratos frequentemente enfatizavam o luxo das vestimentas, mais do que o clima em torno da pessoa representada, ou mesmo a sugestão de sua personalidade, no que reside uma das grandes inovações de Leonardo da Vinci. Ao longo dos séculos, muitos intelectuais se ocuparam em interpretar a obra e, sobretudo, o invulgar sorriso da retratada. Freud, em especial, dedicou-se a pensar acerca da relação que o próprio Leonardo teria com Lisa di Gherardo e, por conseguinte, com a imagem, vide o fato de nunca tê-la repassado aos encomendantes (Freud, 2001). O rei Francisco I, da França, último mecenas do artista, foi quem a adquiriu, em 1518. Mona Lisa integra a coleção do Louvre, em Paris, desde 1797. 
passagens esdrúxulas da política, da indústria do entretenimento, do cotidiano. A presença viral da Mona Lisa comprova não apenas sua imensa notoriedade e o espírito jocoso dos que dela se apropriam, como testemunha de modo inequívoco a nossa condição hodierna, de "civilização da imagem", ou, como ironiza Gilles Deleuze (2007), de "civilização do clichê". ${ }^{3}$

Motivado a pensar na eficácia comunicativa das imagens, o historiador da arte Ernst Gombrich dedicou muitos de seus ensaios ao binômio arte-comunicação, problematizando os padrões visuais e a compreensão dos significados, por parte do público. No artigo "A imagem visual: seu lugar na comunicação" (Gombrich, 2012), ele confronta o leitor com reproduções de pinturas, gravuras, relevos escultóricos, desenhos, fotografias, diagramas, símbolos, cartuns, entre outros, para chamar atenção acerca das muitas coisas que deixamos de questionar quando olhamos para uma imagem, buscando sua mensagem. ${ }^{4}$ Desdobrando exemplos tão díspares como vitrais do século XIII instalados na Catedral de Chartres, rótulos comerciais e uma pretensa e curiosa tentativa de comunicação com seres extraterrestres, enviada pela Nasa na sonda espacial Pioneer F (1972), ele escancara, a todo instante, algo plenamente conhecido, mas às vezes desdenhado: a informação que extraímos de uma imagem, de qualquer imagem, pode ser totalmente diversa da intenção de seu autor. Uma vez que isso vale até mesmo para as imagens publicitárias, vocacionadas a minimizar ruídos, o que dizer daquelas oriundas do campo artístico, calcadas em repertório frequentemente erudito, quando não expressões das subjetividades e inquietações de seus criadores? Todavia, como vimos no exemplo que abriu este texto, elas são amiúde pinçadas de suas conjunturas para assumir outros papéis, veicular diferentes discursos, conferir privilégio e distinção a círculos variados. Essa operação é feita, na maioria das vezes, sem qualquer constrangimento.

3 O fato é que a mídia digital e as novas tecnologias franquearam os trânsitos e os usos das imagens, numa dimensão talvez nunca concebida pelos que se voltaram a discutir o tema - vide Walter Benjamin (1987), em seu texto fundador sobre o assunto e amplamente conhecido, "A obra de arte na era de sua reprodutibilidade técnica", de 1936. Pensemos na "era Google": se essa repercute no cotidiano de milhares de pessoas, interessadas nas matérias mais heterogêneas, o que dizer de seu papel para os que estudam arte? Além de oferecer aos computadores conectados em rede o acesso a reproduções de centenas de obras-primas, essas, com frequência, encontram-se disponíveis em alta ou altíssima definição, revelando pormenores que mesmo o olho humano, diante do original, teria dificuldade em captar - ainda mais com vidro e barreira de cinco metros, como acontece com a... Mona Lisa.

4 O artigo foi originalmente publicado em Scientific American (Gombrich, 1972). 
Longe de censurar a liberdade criativa dos que pautam seus trabalhos no fascinante acervo da história da arte, o que se preconiza é um exame acurado da imagem e de seu contexto de criação, respeitando e considerando sua trajetória, seus valores, suas potencialidades sígnicas.

Nunca é demais recordar que, como sistema de compreensão e de representação simbólica do mundo, a arte não é reflexo, mas agente da história. Isso significa, tomando as palavras de Giulio Carlo Argan (1994, p. 17), que a obra de um grande artista "[...] é uma realidade histórica que não fica atrás da reforma religiosa de Lutero, da política de Carlos V, das descobertas científicas de Galileu. Ela é, pois, explicada historicamente, como se explicam historicamente os fatos da política, da economia, da ciência." A obra de arte, portanto, não é um acontecimento estético que tem também um interesse histórico: é um acontecimento que possui valor histórico porque tem valor artístico. E esse valor, para ser efetivamente preservado, precisa ser conhecido, em sua materialidade, em sua carga simbólica, em suas várias funções sociais. Um dos papéis do historiador da arte está relacionado, justamente, à salvaguarda desse patrimônio, dessa memória.

\section{Tema, imagem: diálogo sintético}

Desde que surgiu, em 1995, a revista Horizontes Antropológicos é referenciada pela qualidade e pela consistência de seus artigos, bem como pelas instigantes capas ilustradas, que fogem ao padrão mais previsível e burocrático, geralmente encontrado nos periódicos acadêmicos. Em meio a soluções fotográficas e a montagens digitais, destacam-se as capas que reproduzem obras de arte. São muitas, mais de 20 , em sua quase sempre direta aliança entre "tema do dossiê" e "imagem". Exemplos: as curiosas fisionomias humanas de Giuseppe Arcimboldo (1527-1593), construídas a partir da sobreposição lúdica e espirituosa de formas de frutas, legumes ou livros, estabelecem relação com os assuntos "Comida" (número 4) e "Tecnologias de governo: etnografias de práticas e políticas" (número 46). ${ }^{5}$ Isso igualmente ocorre ao observarmos a interpretação

5 As obras tomadas são, respectivamente: (1) Outono, 1573; óleo sobre tela, $77 \times 63 \mathrm{~cm}$; Musée du Louvre, Paris, França; e (2) O livreiro (retrato de Wolfgang Lazius), 1562; óleo sobre tela, $97 \times 71 \mathrm{~cm}$; Skoklosters Slott, Estocolmo, Suécia. 
de Gian Lorenzo Bernini (1598-1680) para o rapto de Proserpina (1622), adotada no número 42, cuja pauta foi "Sofrimento e violência". 6 Ou, ainda, no número 38 , com tema "Antropologia e estilos de vida", que traz um excerto da pintura conhecida como Festa de casamento (1568), de Pieter Brueghel (1525-1569), um dos primeiros artistas a representar o cotidiano dos camponeses. ${ }^{7}$ Uma associação mais sutil está na capa do número 16, dedicada ao binômio "Natureza e cultura", que estampa um detalhe da Vênus celestial de Sandro Botticelli (1445-1510), imagem arquetípica do Renascimento. ${ }^{8}$

6 Numa disputa simbólica com a magistral escultura de Giambologna (1529-1608), O rapto de uma sabina (1579-1583) - instalada na Loggia dei Lanzi, em Florença -, a obra de Gian Lorenzo Bernini representa, com um naturalismo desconcertante, o mito greco-romano de Proserpina, filha da deusa Deméter, raptada por Hades e separada, desde então, de sua mãe, bem como do próprio Olimpo. Com seus quase três metros de altura, a escultura em mármore encontra-se na Galleria Borghese, em Roma.

7 A obra, um óleo sobre tela com $114 \times 162,5$ cm, encontra-se no Kunsthistorisches Museum, em Viena. Sobre a atuação de Brueghel, vale um comentário: o artista, que era um homem de certa erudição - vide, inclusive, as amizades que cultivou, entre elas com o eminente geógrafo Abraham Ortelius (1527-1598) -, representou, em muitas de suas telas, hábitos e comemorações populares de camponeses, eventos aos quais ele próprio comparecia. Acerca disso, temos o depoimento de seu biógrafo, Karel van Mander (1548-1606): “.... Executou muitos quadros [em Antuérpia] para um mercador, Hans Franckert, homem muito nobre e íntegro, que achava prazer na companhia de Brueghel, com ele privando todos os dias. Foi com este Franckert que Brueghel fez viagens frequentes ao campo, para observar os camponeses nas suas feiras e casamentos. Disfarçados de camponeses, chegavam levando presentes, como os demais convidados, afirmando ter relação ou parentesco com a noiva ou o noivo. Ali Brueghel se deleitava na contemplação do comportamento burlesco das gentes do campo, da maneira como comiam, dançavam ou se cortejavam, e tudo soube reproduzir com engenho e de forma agradável. [...] Representou os camponeses - homens e mulheres de Kempen e de outras localidades - com naturalidade, tal como eram, revelando a sua rudeza nos modos de andar, de estar ou de se mover" (cf. Janson, 2010, p. 670).

8 A obra de Botticelli - em especial as pinturas Alegoria da primavera (1478-1482) e O nascimento de Vênus (1486), ambas preservadas na Galleria degli Uffizi, em Florença - foi profusamente estudada pelo historiador da arte alemão Aby Warburg (1866-1929). Desconsiderando o modelo cronológico e a tradição formalista da história da arte e interessado, por outro lado, em problematizar a continuidade, as rupturas e as formas de sobrevivência da tradição clássica, Warburg deu início a uma nova abordagem teórico-metodológica da imagem, pensando-a como "fenômeno antropológico total", ou seja, como cristalização, como condensação particularmente significativa de uma cultura em um determinado momento de sua história. Isso o permitia falar em um "poder mito-poiético da imagem", articulado pela memória coletiva, categoria central de seu pensamento (Warburg, 2013). Entre os historiadores da arte ligados ao "Círculo Warburg" e a seus desdobramentos estão alguns dos mais importantes pesquisadores do século XX, como Carlo Ginzburg, Edgar Wind, Ernst Gombrich, Erwin Panofsky, Rudolf Wittkower, Michael Baxandall, Svetlana Alpers e Georges Didi-Huberman. 


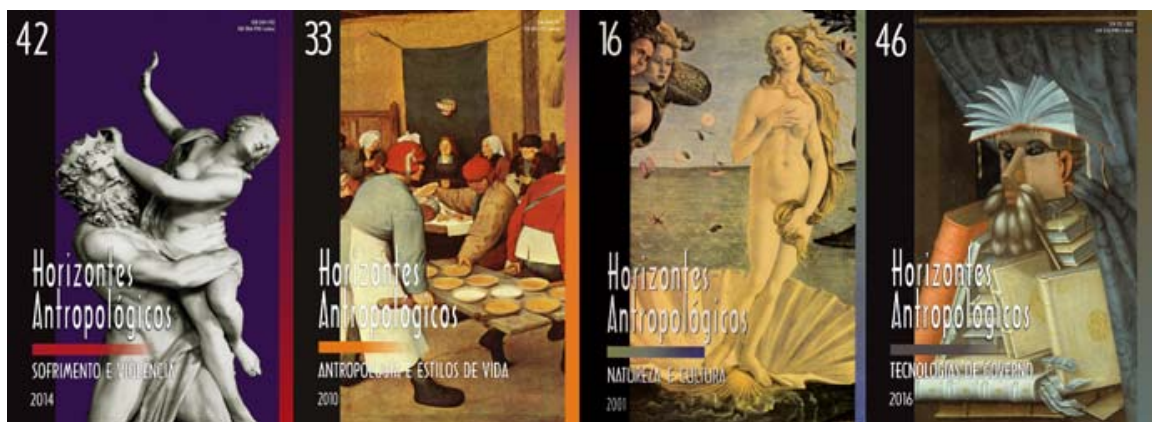

Pensadas a partir de um diálogo sintético com os temas dos dossiês, as imagens assumem a função de ilustração, e acabam conferindo não somente à capa, mas à publicação como um todo, a sua personalidade. Convém, aqui, rapidamente recuperar o sentido de uma "capa".

Em uma publicação impressa, a capa tem propósitos a assumir. ${ }^{9}$ Se, na gênese do formato códice, no século V, o seu encargo maior era "resguardar" o miolo, ao longo do XIX, com o desenvolvimento e a concorrência do mercado editorial, ela ganhou novo compromisso e status: além de proteger e informar, precisava "vender o produto", assumindo um papel privilegiado nos processos de comunicação e sendo a face visível e instantânea do conteúdo.

A atividade editorial consagrou a indicação sumária, na ficha técnica, do(a) autor(a) da capa, ou seja: indica-se o nome do(a) ilustrador(a), do(a) fotógrafo(a), do(a) designer, dificilmente havendo qualquer espaço para notas ou comentários. Os organizadores de Horizontes Antropológicos, sem embargo, mantêm o interessante costume de fechar as apresentações de cada fascículo com uma glosa sobre a imagem de capa. No número 34, reservado ao tema "Antropologia e ciclos de vida", lemos:

Para finalizar, a ilustração da capa deste número reproduz uma imagem da "árvore da vida", de origem mexicana. Esse objeto, fotografado por Cornelia Eckert,

9 Por definição, a capa é um plano único que envolve o miolo da publicação, sendo composta por três faces: (1) a capa em si, ou painel frontal, (2) a lombada e (3) a contracapa. Apesar de o termo designar essas três partes, fisicamente ligadas entre si, é também usado para falar apenas do painel frontal, o mais visível e importante dos três. 
pertence a uma tradição popular milenar, enraizada na lógica mítica e cosmológica mesoamericana. A escolha dessa imagem se deve tanto à sua beleza plástica e força simbólica quanto à sua estreita relação com o tema deste número de Horizontes Antropológicos, que nos remete aos processos dos ciclos de vida que perpassam os tempos e as culturas. (Eckert; Steil, 2010, p. 15).

O texto explica, de modo conciso, a imagem e sua simbologia, justificando-a como emblemática para sumariar a publicação. Mas há os casos em que o argumento parece compulsório:

Ao contrário do que se poderia imaginar, a ilustração da capa deste número de Horizontes Antropológicos não traz uma foto de um supermercado ou de um shopping center. Resolvemos, em vez disso, reproduzir o Abaporu, quadro de 1928 da fase antropofágica da pintora modernista Tarsila do Amaral, que se encontra atualmente no Malba (Museu de Arte Latino-Americano de Buenos Aires). A pintura foi adquirida em um leilão em Nova Iorque, em 1995, por Eduardo Constantini, empresário argentino e fundador do museu, por U\$ $1.430 .000,00$, o mais

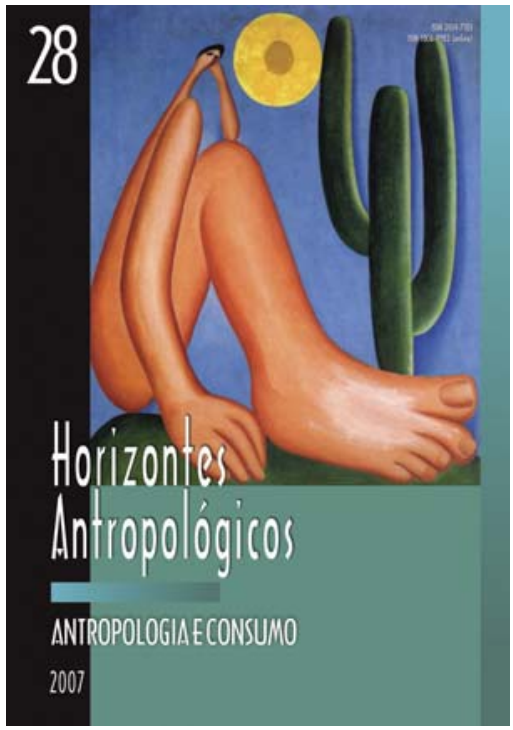
alto valor pago até então por uma obra de arte brasileira. O proprietário anterior havia tentado, durante meses, vendê-la no Brasil. Alguns anos depois, um grupo de empresários brasileiros tentou comprar o quadro de volta para repatriá-lo. Constantini negou-se a vendê-lo. Segundo ele, "o Abaporu está para o Malba assim como a Mona Lisa está para o Louvre". (Oliven; Pinheiro-Machado, 2007, p. 13).

O Abaporu condensa, por um vínculo oblíquo, as relações entre antropologia e consumo, foco do número 28 da revista; e respinga, como vemos, em bens simbólicos altamente valorizados, como são as obras de arte, haja vista a ênfase no 
montante pago pela pintura e na negativa categórica, por parte de seu proprietário, de revendê-la.

"Mona Lisa do Malba", O Abaporu é a mais icônica obra de arte brasileira, assinalando um momento de zênite da cultura nacional. Sua presença, em um museu argentino, faz com que muitas pessoas sintam um misto de perplexidade e vergonha: como deixaram a obra sair do País? No dia $1^{\circ}$ de outubro de 1995, pouco antes do leilão na Casa Christie's, em Nova Iorque, o jornalista Elio Gaspari publicou em sua coluna no jornal O Globo uma entrevista com o colecionador Raul Forbes, detentor da obra. Perguntado sobre por que estava vendendo o quadro, ele respondeu: “Precisava de dinheiro" (cf. Gomide, 2014, p. 28). Simples assim...

\section{Autofagia}

Tarsila do Amaral (1886-1973) concluiu O Abaporu em janeiro de 1928, oferecendo-o como presente de aniversário ao seu então marido, o poeta Oswald de Andrade (1890-1954). Cosmopolitas, audazes e ricos, eles viviam entre São Paulo e Paris, formando a dupla conhecida como "Tarsiwald", na feliz expressão de Mario de Andrade (1893-1945). Tarsila, naquele momento, colhia os frutos de sua bem-sucedida exposição individual na Galeria Percier, em Paris (junho de 1926), quando exibiu algumas de suas pinturas mais significativas, todas da chamada fase "Pau Brasil", em diálogo com as propostas poéticas de Oswald. ${ }^{10}$ Produzidas entre 1924 e 1927, as imagens desse período são exemplares do projeto modernista de matriz paulistana, que, em seu primeiro momento, buscava fazer a difícil conciliação entre internacionalismo e nacionalismo, rural e urbano, primitivo e vanguardista. "Pintando em brasileiro", Tarsila criou obras-primas como A negra (1923), A cuca (1924), Carnaval em Madureira (1924), São Paulo (135831) (1924), São Paulo/Gazo (1924) e Vendedor de frutas (1925), ao que Oswald aplaudia: "Bárbaro e nosso."

Em janeiro de 1928, ao finalizar O Abaporu, Tarsila estava, sem saber, dando início a um marco cultural dos anos 1920: o movimento antropofágico.

10 O Manifesto Pau Brasil foi publicado por Oswald de Andrade, no jornal Correio da Manhãa, do Rio de Janeiro, no dia 18 de março de 1924. Em 1925, o escritor lançou o livro de poesias Pau Brasil, com capa e ilustrações de Tarsila. As ideias defendidas nesses textos, conciliando o primitivo e o moderno, o local e o universal, foram as bases para os processos modernistas, a partir dos anos 1920, em São Paulo. 
[...] uma figura monstruosa, pés imensos, sentada numa planície verde, o braço dobrado repousando num joelho, a mão sustentando o peso-pena da cabecinha minúscula. Em frente, um cactus explodindo numa flor absurda. [...] Oswald de Andrade e Raul Bopp, [...] chocados, [...] contemplaram-no longamente. Imaginativos, sentiram que dali poderia surgir um grande movimento intelectual. (Amaral, 1972 apud Gotlib, 1998, p. 152).

Desconcertados diante da figura colossal, comprimida na superfície de $85 \times 73 \mathrm{~cm}$, resolveram batizá-la. Folheando o dicionário de termos indígenas de Antonio Ruiz de Montoya, encontraram as palavras "aba", homem, e "poru", que come carne humana. Perfeito: "abaporu”, o homem que come carne humana.

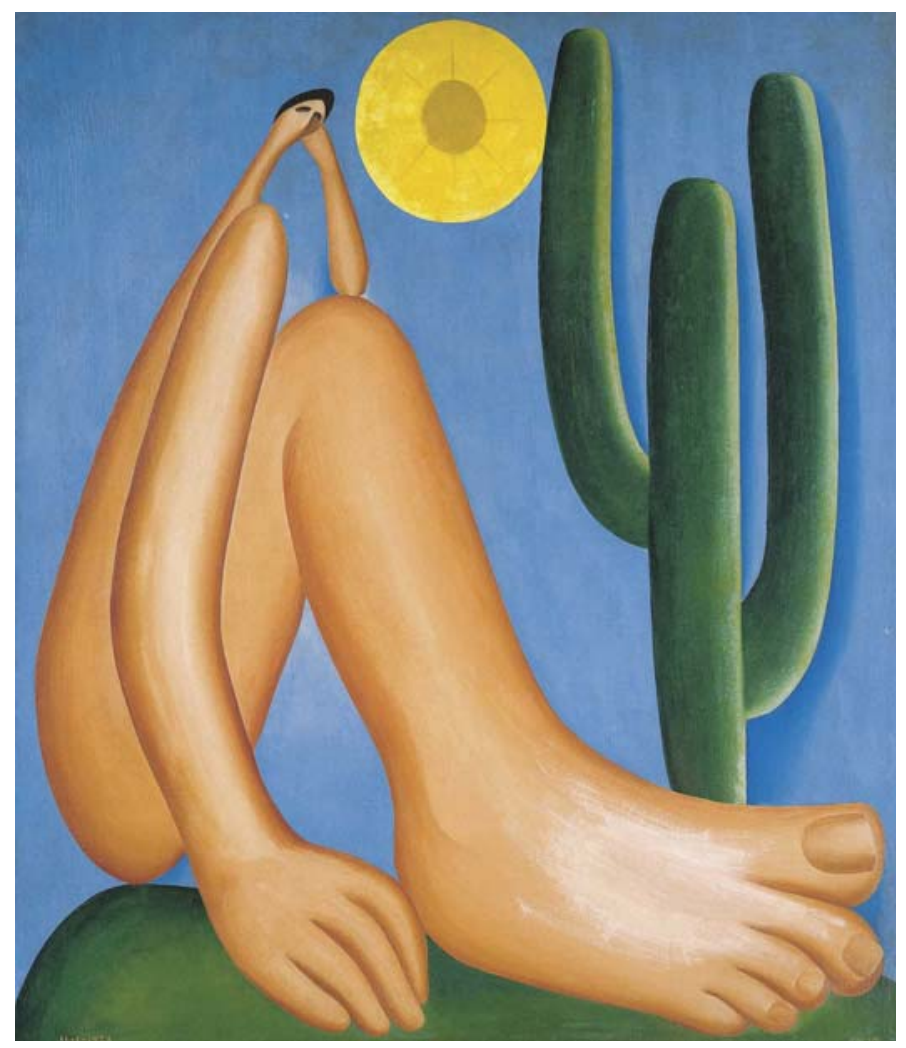

Figura 2. Tarsila do Amaral (1886-1973), O Abaporu, 1928, óleo sobre tela, $85 \times 73$ cm, coleção Eduardo Constantini, Malba, Buenos Aires, Argentina. 
Com seu estranhamento perturbador, o quadro foi a motivação para que Oswald escrevesse o Manifesto Antropófago, lançado em maio de 1928 e que circulou com a reprodução, em traço, da figura criada por Tarsila. Saudando o selvagem sem as miçangas da catequese, o texto pregava o abandono do racionalismo ocidental em prol de um primitivismo libertador, ao mesmo tempo em que defendia a devoração simbólica do outro para, a partir da absorção de suas qualidades essenciais, produzir algo singular:

Só a antropofagia nos une. Socialmente. Economicamente. Filosoficamente.

[...] Tupi or not tupi that is the question.

Contra todas as catequeses. E contra a mãe dos Gracos.

Só me interessa o que não é meu. Lei do homem. Lei do antropófago.

[...] Queremos a revolução Caraíba. Maior que a revolução Francesa. A unificação de todas as revoltas eficazes na direção do homem. Sem nós a Europa não teria sequer a sua pobre declaração dos direitos do homem.

A idade de ouro anunciada pela América. A idade de ouro. E todas as girls.

[...] Tínhamos a justiça codificação da vingança. A ciência codificação da magia. Antropofagia. A transformação permanente do tabu em totem. [...] ${ }^{11}$

Mas o mistério em torno da figura selvática permanecia. Como, enfim, a artista havia chegado àquelas formas? Em entrevista à revista Veja, publicada em 23 de fevereiro de 1972, ela comentou:

Devia ser uma lembrança psíquica ou qualquer coisa assim e me lembrei de quando nós éramos crianças na fazenda. Naquele tempo, tinha muita facilidade de empregadas: aquelas pretas que trabalhavam para nós na fazenda, depois do jantar, elas reuniam a criançada para contar histórias de assombração, iam contando da assombração que estava no forro da casa. Eu tinha muito medo, a gente ficava ouvindo, elas diziam: daqui a pouco, da abertura, vai cair um braço, vai cair uma perna, e nunca esperávamos cair a cabeça, abríamos a porta correndo e nem

11 O Manifesto Antropófago foi publicado na edição ${ }^{\circ} 1$ da Revista de Antropofagia, de maio de 1928. Dirigida por António de Alcântara Machado (1901-1935), com gerência de Raul Bopp (1898-1984), a revista teve "duas dentições": a primeira, entre maio de 1928 e janeiro de 1929, contou com dez números, que circularam mensalmente; a segunda, entre março e agosto de 1929, consistia na publicação semanal de uma página no jornal Diário de São Paulo. 
queríamos saber de ver cair a assombração inteira. Quem sabe o "Aba-Poru” é um reflexo disso? (Amaral, 1972 apud Gotlib, 1998, p. 144).

Roteiros. Roteiros. Roteiros. Roteiros. Roteiros. Roteiros. Roteiros. Corpo mutilado, corpo reconstruído. Para a pesquisadora Icleia Cattani, o antropófago de Tarsila representa, na verdade, o mito do país jovem, voraz em seu desejo de vencer e capaz de incorporar, em sua arte, múltiplos modelos, para criar o novo.

A pintura de Tarsila elaborou plasticamente esse mito que se manifesta primeiramente pelas migrações, substituições, metamorfoses e desdobramentos do corpo. O corte circular do espaço, o recentramento da expansão da cor, sua intensidade similar e a regularidade de seu modelado, a monumentalidade, o hieratismo e a frontalidade das figuras também propiciam o aparecimento dos mitos, a circularidade do périplo mítico que volta sempre às origens, a intemporalidade e os percursos reversíveis. (Cattani, 2011, p. 50).

A própria Tarsila compreendeu, rapidamente, a importância de sua pintura e o que ela suscitava. Na obra Antropofagia (1929), a artista "devorou a si mesma", fundindo suas obras mais paradigmáticas: A negra (1923), início da fase "Pau Brasil", ponto de partida de seu périplo, e O Abaporu (1928), marco da sua fase "Antropofagia", ponto de chegada. Tão ou mais forte que qualquer texto ou manifesto, o seu projeto estético e cultural para o Brasil estava pulsando naquelas imagens, como ainda hoje pulsa, ensinando-nos que não tínhamos visto o que agora vemos.

Em 1930, "Tarsiwald" não existia mais. Na divisão dos bens, Oswald abriu mão d'O Abaporu, que foi comprado, na década de 1960, pelo italiano Pietro Maria Bardi (1900-1999), responsável, junto com Assis Chateaubriand (18921968), pela criação do Museu de Arte de São Paulo, em 1947. Bardi, diretor do Masp por 45 anos ininterruptos, atuava, concomitantemente, como marchand junto à galeria Mirante das Artes, alimentando, com isso, inúmeras - e legítimas - críticas. Foi nessa condição que, podendo encaminhar a pintura ao museu, vendeu-a ao colecionador Erico Stickel, de São Paulo. Em 1984, O Abaporu teve seu primeiro marketing de vendagem, quando passou para as mãos de Raul Forbes, por US\$ 250 mil, o preço mais alto pago, até então, por uma obra brasileira. Cerca de uma década depois, quebrou o seu próprio recorde, mas em 
âmbito internacional, no já citado leilão da Christie's. Após ter migrado para a Argentina, integrando a coleção do empresário Eduardo Constantini, O Abaporu visitou o Brasil pelo menos duas vezes: em 2011, em evento no Palácio do Planalto, em Brasília; e, em 2016, durante as Olimpíadas no Rio de Janeiro, quando, para cálculos de seguro, seu valor foi aquilatado em surpreendentes US\$ 40 milhões.

O caso d'O Abaporu é umbrátil, mas não o único. Em 2007, a Coleção Adolpho Leirner, a mais importante de arte construtiva brasileira, foi vendida ao Museum of Fine Arts de Houston, nos Estados Unidos, por um valor estimado em US\$ 15 milhões. Reunindo obras fundamentais dos anos 1950-1960, de artistas como Samson Flexor (1907-1971), Waldemar Cordeiro (1925-1973), Lygia Clark (1920-1988) e Helio Oiticica (1937-1980), a coleção foi oferecida a várias instituições museais do País, mas nenhuma se movimentou para angariar os fundos necessários à compra. "Produto" que também é, a coleção formada ao longo de décadas acabou em território estadunidense. A celeuma decorrente desse e de tantos outros casos evidencia a ausência não somente de políticas voltadas à aquisição de obras e à manutenção de acervos importantes para a história nacional, mas - o que talvez seja mais constrangedor - de efetivo interesse público.

\section{Quem se importa?}

A situação comentada acima não é privilégio de países com pouca tradição de investimentos em acervos e museus. Uma das últimas pinturas de Rembrandt van Rijn (1606-1669), A conspiração dos batavos sob Claudius Civilis (1666), também não está em seu país de origem, mas no National Museum de Estocolmo, na Suécia.

Simon Schama, em emocionante ensaio dedicado a Rembrandt, expõe as fatalidades em torno da obra, encomendada pela elite de Amsterdam para a nova prefeitura. Narrando visualmente o momento da insurreição batava contra o Império Romano, comandada pelo líder Claudius Civilis, no século I, a imagem tomava conta do hall do edifício público, mas foi retirada do espaço e devolvida ao artista: era forte demais, incomodava demais. Rembrandt, falido e idoso, tentando encontrar um comprador para a pintura e num ato de 
desespero, cortou-a, reduzindo sua dimensão a $20 \%$ de seu tamanho inicial e alterando irreversivelmente a maneira como o espectador a veria. ${ }^{12} \mathrm{Em} 1734$, transcorridos 65 anos de sua morte, um batavo-sueco comprou a tela indesejada por 60 florins, o preço de um bom móvel para a casa.

Assim, a pintura que mais que qualquer outra versa sobre a pátria, a tribo vista em seu momento de autorreconhecimento, está no exílio, a quase mil quilômetros do lugar para o qual foi criada. Devia ser a glória de Amsterdam, a obra que todo visitante iria ver na sede da prefeitura (hoje um palácio real). Mas foi embora. E nunca se faria nada igual - nem na Holanda nem em lugar nenhum. (Schama, 2010, p. 137).

O "tosco na sala dos ricos", como define Simon Schama, Rembrandt viveu o esplendor e a miséria, o reconhecimento e o desprezo, sendo autor de obras magníficas da história da arte. Uma das mais conhecidas é A lição de anatomia do Dr. Nicolaes Tulp (1632), parcialmente reproduzida na capa do número 44 de Horizontes Antropológicos, devotada ao tópico "Cultura e aprendizagem".

Com um tratamento de luz e composição incomuns, a imagem representa o que seria uma aula de anatomia na Holanda do século XVII.

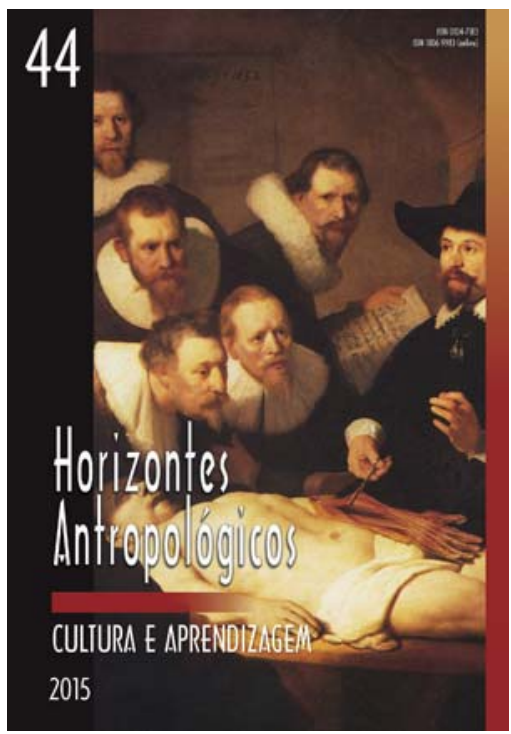
A prática da dissecação de cadáveres humanos ainda era tabu em muitas regiões da Europa. Mas, na progressista, opulenta, majoritariamente calvinista e recém-fundada República Holandesa, era algo fundamental para a divulgação científica, lembrando que ali estavam algumas das mais importantes casas editoras do período, de cujas oficinas

12 Mesmo assim, o que restou do quadro mantém dimensões consideráveis: $196 \times 309 \mathrm{~cm}$. 
saíam livros ilustrados sobre história natural, óptica, astronomia, biologia, além de exemplares únicos de cartografia.

Nascido na cidade de Leiden, célebre por suas manufaturas têxteis, o "filho do moleiro" estabeleceu-se em Amsterdam, em 1631, depois de ter impressionado o diplomata Constantijn Huygens (1596-1687), a serviço do príncipe de Orange, com suas interpretações de temas do Antigo Testamento. É curioso observar que Rembrandt poderia ter ido para Haia, mas elegeu a "nova Veneza", pórtico e palco para os produtos mais luxuosos e extravagantes que circulavam no Velho Mundo, comercializados pelas duas potentes agremiações de mercadores da Holanda: a Companhia das Índias Orientais, criada em 1602, e a Companhia das Índias Ocidentais, surgida em 1621. O jovem artista apostou, destarte, no futuro comercial, em detrimento do passado áulico.

Mestre absoluto em seu ofício, Rembrandt conseguia articular, pelo menos, duas grandes qualidades: (1) perícia descritiva, a partir da qual reproduzia com minúcia a superfície e a textura do mundo material, de tecidos a metais, passando por rugas e fios de cabelo, e (2) eficácia dramática, transformando seus clientes em intérpretes absolutos das paixões humanas. Era tudo que comerciantes, banqueiros e novos-ricos buscavam. Em pouco tempo, ele se consagrou como o mais destacado retratista de Amsterdam, produzindo, entre 1631 e 1633, cerca de 50 pinturas, exemplares notáveis do "flamejante teatro da vida burguesa" (Schama, 2010).

Foi nessa conjuntura que o pintor e gravador, então com 26 anos, recebeu uma importante encomenda: o retrato do Dr. Nicolaes Tulp, anatomista oficial da cidade, realizando uma dissecação pública. Segundo o pesquisador português João-Maria Nabais, o primeiro evento nesses moldes ocorreu em Praga, no ano de 1600, conduzido por Ján Jezenský (1566-1621). Na época, era costume realizar uma autópsia por ano, sempre durante o inverno, visando à melhor conservação dos corpos que, via de regra, eram de ex-condenados, vítimas de enforcamento. Como um "maravilhoso espetáculo", esses episódios eram abertos a estudantes e curiosos, que compareciam elegantemente vestidos, como convinha a solenidades, pagando bilhete de entrada (Nabais, 2008-2009). Não demorou para que a prática se tornasse corrente na República Holandesa, vide as pinturas que adornavam a Guilda dos Cirurgiões de Amsterdam, tais como A lição de anatomia do Dr. Sebastiaen Egbertsz (1603), de Aert Pietersz (1550-1612); A lição de osteologia do Dr. Sebastiaen Egbertsz (1619), 
de Thomas de Keyser (1596-1667); e as duas "lições de anatomia" do Dr. Frederik Ruysch: a primeira de 1670, produzida por Adriaen Backer (1635-1684), e a segunda de 1683, de Jan van Neck (1634-1714). ${ }^{13}$

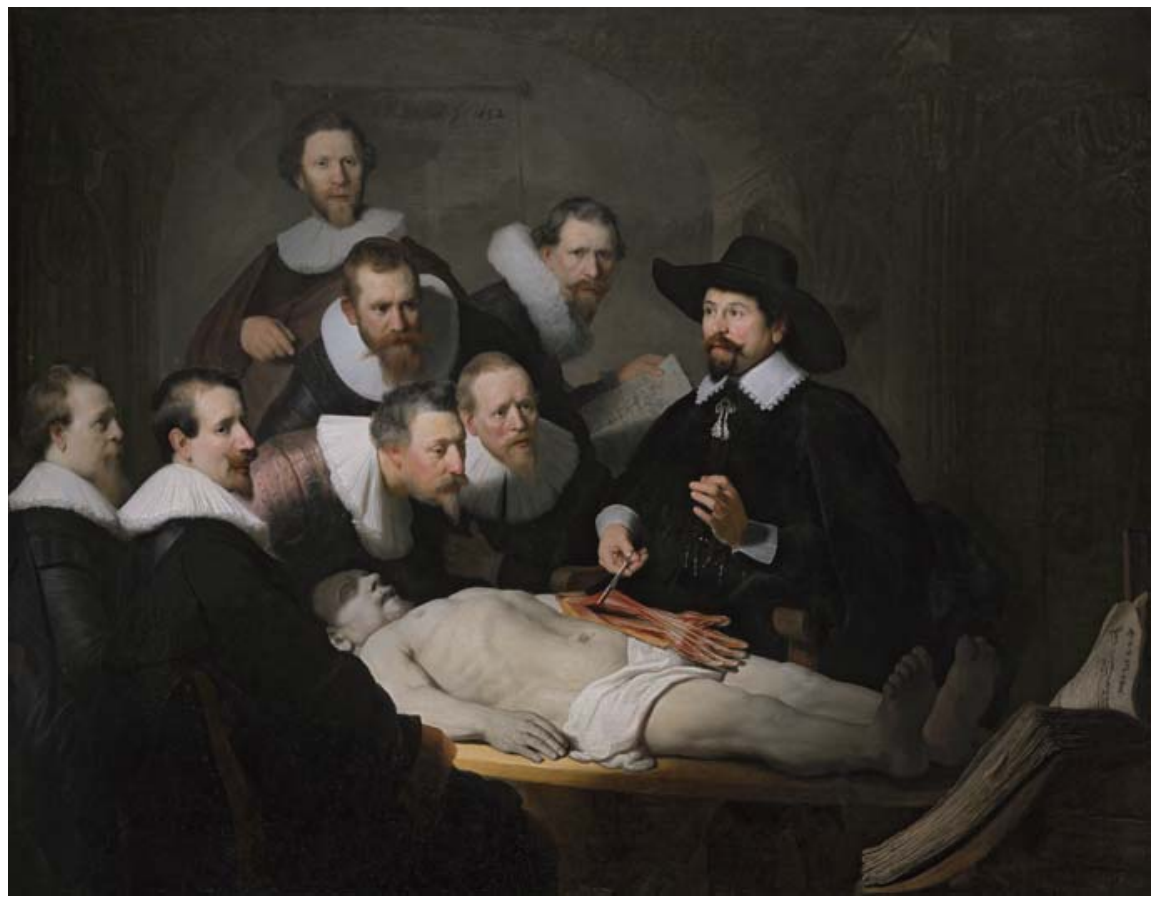

Figura 3. Rembrandt van Rijn (1606-1669), A lição de anatomia do Dr. Nicolaes Tulp, 1632, óleo sobre tela, 169,5 × $216 \mathrm{~cm}$, Mauritshuis, Haia, Holanda.

Nesse rol, a obra de Rembrandt, que memoriza o acontecimento ocorrido em janeiro de 1632, sobressai-se. Dinamizando o retrato de grupo, o artista representa os nove personagens em indisfarçada tensão. Dois deles se projetam: o médico e anatomista Nicolaes Tulp (1593-1674), com seus 39 anos de idade, e Aris Kindt, o cadáver. De acordo com especialistas da área médica, a

13 Frederik Ruysch (1638-1731), notável por seus estudos em botânica e embalsamento de corpos, teria sido responsável por mais de 30 dissecações públicas em Amsterdam. Todas as obras citadas encontram-se no Amsterdam Museum. 
representação da dissecação em si está equivocada, mas quem se importa? Empregando um tratamento de luz cênico, Rembrandt explora o drama pelo olhar dos personagens: há os que observam ambiguamente o evento; há os que se debruçam, atentos, guiados pela explanação mágica de Tulp; também há o que parece olhar para o gigantesco livro aberto, no primeiro plano, à direita - talvez uma alusão ao De humani corporis fabrica (1543), de Andreas Vesalius (1514-1564), aclamado como pai da anatomia moderna; mas há o que, num sombrio comentário sobre a morte e nossa transitoriedade, olha para nós, espectadores. Não por acaso, esse personagem é o que irrompe mais alto, ao lado da proeminente assinatura do pintor, acompanhada do marcador temporal: 1632.

O que a composição bafeja é que Rembrandt estava menos interessado na justa documentação do fato e mesmo nos burgueses que pagaram pela obra, preocupando-se, isso sim, em criar uma imagem eloquente, que não deixasse qualquer dúvida quanto a quem era mais importante ali: o próprio artista.

A mensagem vaporosa e, ao mesmo tempo, precisa, identificada n'A lição de anatomia do Dr. Nicolaes Tulp, atravessa de modo peremptório várias obras canônicas. Talvez a mais flagrante seja O casal Arnolfini (1434), de Jan van Eyck (c. 1390-1441). Nessa imagem secular, o semblante do artista é sugerido no reflexo junto ao espelho convexo, minuciosamente representado no centro do quadro e abaixo da anotação que, em escrita de chancelaria e como um testemunho, informa-nos: Johannes de Eyck fuit hic, ou "Jan van Eyck esteve aqui". ${ }^{14}$ Recado semelhante ecoa, de modo cifrado, em uma obra como $O$ jardim das delícias (1500-1510), de Hieronymus Bosch (c. 1450-1516), adotada na capa do número 47 de Horizontes Antropológicos, voltado ao debate sobre "Gênero e sexualidade, saberes e intervenções". Acerca da escolha da imagem, os editores nos dão o interessante comentário:

[...] Sendo interpretado ora como uma advertência moral contra os pecados e a luxúria de uma humanidade degradada, ora como a celebração de um paraíso

14 Uma das pérolas da National Gallery, em Londres, a pintura é um óleo sobre madeira de carvalho com $82 \times 60 \mathrm{~cm}$ e representa um rico comerciante italiano atuante em Bruges, Giovanni Arnolfini, e sua noiva, Giovanna Cenami, no interior de um aposento. Repleta de simbologias, a pintura é um dos maiores exemplares do Renascimento flamengo. 
perdido, o tríptico de Bosch, como boa parte de sua obra, contém um conjunto de figuras e elementos perturbadores, cujo simbolismo os/as estudiosos/as buscam desvelar. A obra é marcada pela ausência de uma clara diferenciação corporal entre homens e mulheres e pela presença de uma sexualidade difusa e múltipla. As cores suaves e as cenas ao mesmo tempo poéticas e bizarras lembram uma atmosfera de sonho que, segundo André Breton, prefigura o surrealismo do século XX. Pretendemos, com essa imagem, remeter à discussão contemporânea acerca da fluidez e dos deslizamentos entre os corpos e os gêneros, bem como às tensões morais a eles associadas. (Rohden; Russo; Roca, 2017, p. 24).

No Museo del Prado, apenas As meninas, de Velázquez, goza de tanta popularidade como $O$ jardim das delícias. Datada da primeira década do século XVI, a obra é um tríptico articulado, ou seja, é composta de três partes: painel central e duas portas, os chamados "volantes". Quando fechado, o tríptico exibe, no verso dos volantes, uma pálida imagem, em tons acinzentados, representando a criação do mundo. ${ }^{15}$ Ao ser aberto, no entanto, reveste-se de uma miríade de formas e cores, numa cena ímpar para a época, que suscita vários enigmas, a começar pelas refe-

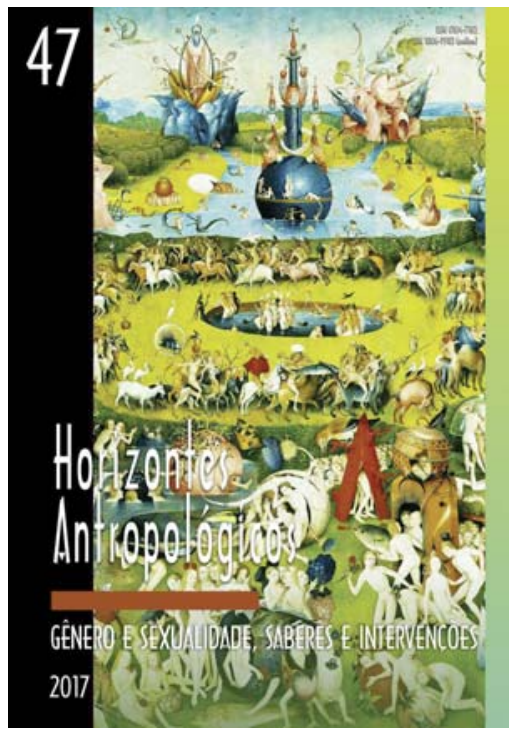
rências do pintor.

Os especialistas que se dedicam a Bosch acreditam que ele jamais saiu de sua cidade natal, Hertogenbosch, também chamada de Bois-le-Duc, topônimo que significa, literalmente, "bosque do duque", remetendo ao fundador

15 Essa imagem tem, no alto, à esquerda, uma representação do Deus cristão e, mais ao centro, dividida nos dois suportes, a inscrição em latim Ipse dixit et facta s(ou)nt / ipse man(n)davit et creata s(ou)nt, ou algo como: "Ele o fez, e tudo foi feito. Ele o mandou, e tudo foi criado", a partir do Salmo 33 da Bíblia. 
da cidadela, Henrique I de Brabante (Bosing, 2010; Koldeweij; Vandenbroeck; Vermet, 2001). Esse "bosque" foi o que o artista incluiu em seu próprio nome, quando deixou de ser "Hieronymus van Aken" para se tornar "Hieronymus Bosch". ${ }^{16}$

Segundo Koldeweij, Vandenbroeck e Vermet (2001), até o século XIV, Bois-le-Duc era a segunda localidade mais populosa do norte da Holanda, com cerca de 14 mil habitantes, perdendo apenas para Utrecht, que contabilizava pouco mais de 17 mil. Em 1463, contudo, um incêndio de grandes proporções arrasou mais de quatro mil casas, matando centenas de pessoas e maculando para sempre a memória dos sobreviventes. O jovem Hieronymus deve ter testemunhado as chamas e a desolação, representando, anos depois, o impacto da tragédia no volante final de muitos de seus trípticos.

O chamado Painel do juízo final, de Viena, ${ }^{17}$ assim como 0 jardim das delícias e $O$ carro de feno, ambos do Prado, ${ }^{18}$ vão, literalmente, do paraíso ao inferno. Enquanto os volantes da esquerda exibem uma representação do Jardim do Éden e do que Adão e Eva estavam sendo privados, após a desobediência representada pelo episódio da serpente, os da direita escancaram o fim último: o triunfo do sofrimento e da morte. No centro, invariavelmente, alucinantes alegorias sobre a própria jornada do homem na Terra.

Sabe-se que Bosch se casou com uma mulher abastada, Aleyt van Mervende, o que lhe permitiu desenvolver uma poética mais autônoma do que seus contemporâneos, comprometidos com encomendas e orientações de seus mecenas. Essa condição torna o artista ainda mais instigante, pois somos convidados a pensar que suas composições eram resultado de uma opção francamente pessoal. Em tal conjuntura, uma pergunta lícita seria: e ele

16 Numa interessante estratégia de diferenciação e visibilidade, pois a família de Bosch tinha vários pintores já conhecidos pelo sobrenome "Van Aken": seu pai, Anthonius van Aken, era pintor miniaturista, assim como haviam sido seu avô Jan e seu bisavô Thomas. Por outro lado, a inclusão do lugar de origem no nome também sugere a ambição de ser conhecido muito além das cercanias de Bois-le-Duc.

17 A obra, com datação presumida entre 1495-1515, foi executada em óleo sobre madeira; tem $167,7 \times 60 \mathrm{~cm}$ (portas) e 163,7 × $127 \mathrm{~cm}$ (painel central), e integra a Gemäldesammlung der Akademie der bildenden Künste, em Viena, Áustria.

18 Também datada entre 1495-1515, O carro de feno tem $147 \times 232 \mathrm{~cm}$ (aberto), é um óleo sobre madeira e está no Museo del Prado, em Madri, Espanha. 
encontrava quem compreendesse ou gostasse dessas obras? A resposta, rápida, é "sim". 19

Reconhecido e aclamado em sua região, Bosch ingressou na elitista Confraria de Nossa Senhora em 1486. A entidade existia desde 1318, e pertencer a ela era um sinal não apenas de devoção católica, mas de prestígio social. Os irmãos confrades defendiam a observância de uma conduta moral ilibada e das rigorosas regras da Igreja. A partir desse dado, suas obras podem ser interpretadas como advertências, num eco do imaginário medieval em torno do tão aguardado "fim do mundo". 20

Em 0 jardim das delícias, a tônica recai sobre as armadilhas dos sentidos. Observando com diligência o painel central, identificamos: (1) a visão sendo engolfada pela beleza do jardim, com sua vívida paleta cromática, notadamente em verdes, azuis, vermelhos e ocres; (2) o olfato sucumbindo ao perfume das

19 O que também nos aponta para um veio pouco comentado pela história da arte: o dos colecionadores ou, se quisermos, o dos "consumidores". A própria trajetória d’O jardim das delícias, nesse sentido, é exemplar: seu primeiro proprietário teria sido Henrique III de Nassau (1483-1538), em cujo castelo, em Breda, atual Holanda, o quadro foi visto e comentado em 1517, pouco depois do falecimento de Bosch. Naquele ano, acompanhando o cardeal Luis de Aragón (1475-1519) à região, Antonio de Beatis, seu secretário particular, registrou o impacto da obra: "Há, ademais, algumas telas com diversas extravagâncias, nas quais se desfiguram mares, céus, bosques, campos e muitas outras coisas [...], mulheres e homens, brancos e negros, em diversos atos e maneiras, pássaros, animais de toda classe e com muita naturalidade, coisas tão agradáveis e fantásticas que a quem não tenha conhecimento delas, de nenhum modo as poderia descrever tão bem" (cf. Gombrich, 1967, p. 403-404, tradução minha). Em 1544, com a morte do filho de Henrique de Nassau, a pintura passou ao seu sobrinho, Guilherme de Orange (1533-1584), grande impulsionador do processo de independência dos Países Baixos, em relação à Espanha. Em 1568, durante as guerras contra a Coroa espanhola, a obra foi confiscada, passando ao militar Fernando de Toledo (1528-1591), prior da Ordem de Malta e membro do Conselho de Estado e da Guerra, de Filipe II (1527-1598). Em 1593, dois anos após seu falecimento, ela foi comprada pelo próprio rei e enviada ao Mosteiro do Escorial, ficando instalada em seu quarto e reforçando o conjunto de nove pinturas que Filipe II tinha do artista. O jardim das delícias permaneceu no Escorial até a Guerra Civil e, em 1939, ingressou na coleção do Museo del Prado como depósito de patrimônio nacional. Sobre os trânsitos da obra, ver a documentação disponível no sítio virtual do Museo del Prado.

20 Em 1947, no entanto, despontou uma abordagem totalmente diversa, defendida pelo historiador alemão Wilhelm Fraenger sob o título Hieronymus Bosch - Das Tausendjährige Reich: Grundzüge einer Auslegung. Segundo ele, Bosch pertenceria à Congregação do Espírito Livre, grupo herético adamita, surgido no século XIII, que procurava recuperar o estado de inocência anterior à "queda de Adão e Eva". Ainda segundo Fraenger, O jardim das delícias, ao contrário da interpretação corrente, seria uma representação das práticas em vigor entre os membros da entidade. Polêmica e sedutora, a hipótese carece de aportes históricos, tendo sido ignorada pelos especialistas (Bosing, 2010). 


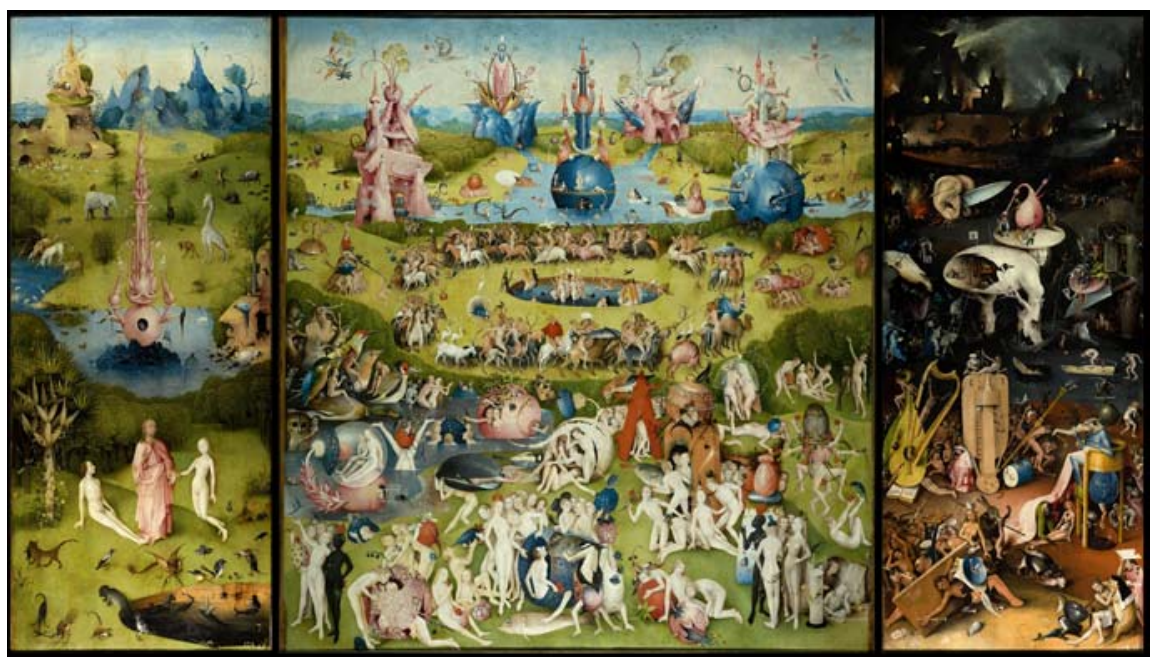

Figura 4. Hieronymus Bosch (c. 1450-1516), O jardim das delícias, 1500-1510, óleo sobre madeira, $135 \times 180 \mathrm{~cm}$ (portas abertas), Museo del Prado, Madri, Espanha.

flores e das frutas; (3) o paladar sendo atraído pelos morangos, amoras e maçãs; (4) a audição rendendo-se ao canto dos pássaros e ao murmúrio das águas que correm; e, por fim, (5) o tato trôpego, diante de tantas possibilidades: fluidez da água, frescor da vegetação, calmaria da atmosfera quente e perfumada, calor dos corpos, vários... de animais, de homens e de mulheres. Tudo parece belo, harmonioso e de acordo; porém, enquanto as pessoas deixam-se envolver pelos prazeres dos sentidos, elas se transformam, sem perceber, em seres bestiais, como que assinalados pelo pecado. ${ }^{21}$

A orgia de formas do painel central mantém-se no último volante, com toda sorte de torturas, mutilações, referências fálicas e anais. O inferno, para Bosch, é dominado pelo caos, pela jogatina, pela música, pelo fogo. Nesse sentido, consciente de sua condição de pecador, Bosch teria emprestado seu rosto a uma das figuras mais aterradoras d'O jardim das delícias, o chamado "homem-árvore".

21 É de se comentar que mesmo no volante que representa o Paraíso não há perfeição; vários animais despontam híbridos e monstruosos, apesar de estarem ao lado de Cristo. Trata-se de um elemento desestabilizador, que alimenta interpretações muito distintas acerca dessa e de tantas outras imagens, bem como em torno do próprio artista. 
Disposto na parte central superior, o personagem aparece com o corpo frágil e híbrido, tronco em formato oval e membros como galhos, apoiados sobre barcos instáveis. Ele é a própria taverna, sinalizada pela bandeirola e pelas pessoas decrépitas, próximas a um barril de bebida; arruinado, em meio à expiação de seus pecados, o personagem volta o rosto e nos encara com expressão grave, como a nos questionar se queremos, após a morte, futuro semelhante. ${ }^{22}$

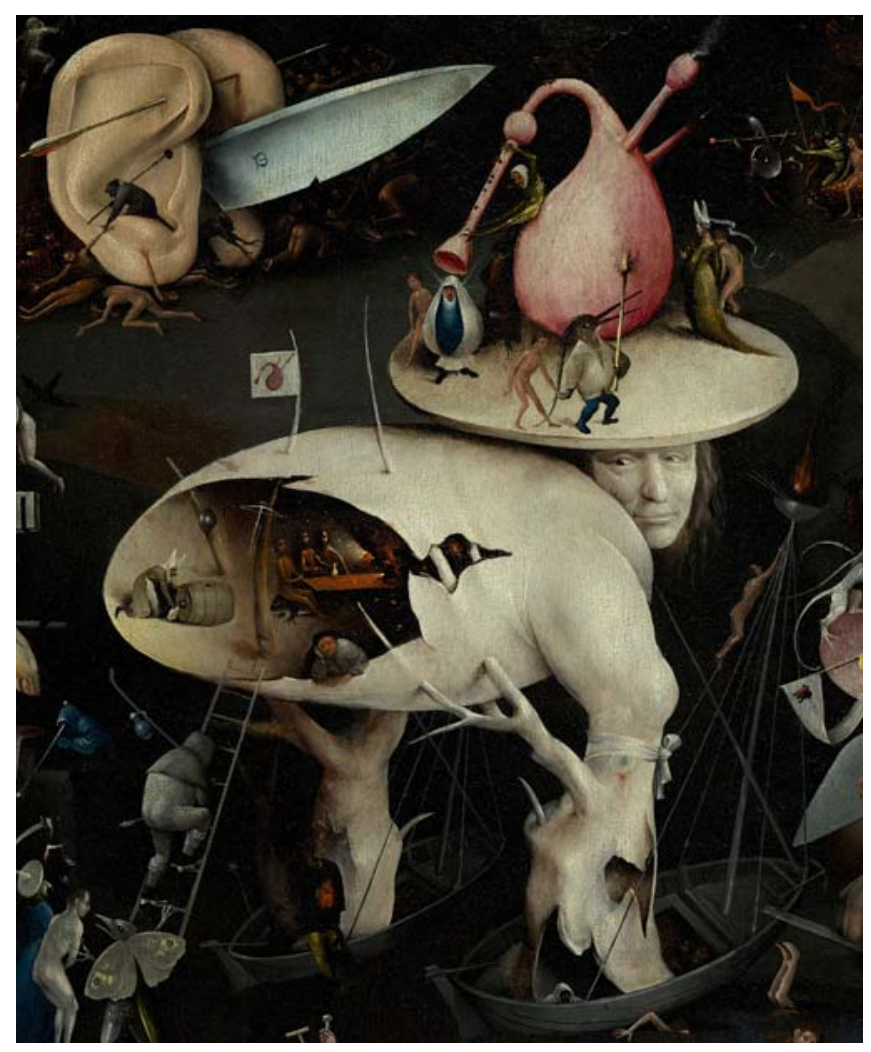

Figura 5. Hieronymus Bosch (c. 1450-1516). O jardim das delícias (detalhe), 1500-1510, óleo sobre madeira, $135 \times 180 \mathrm{~cm}$ (portas abertas), Museo del Prado, Madri, Espanha.

22 O "homem-árvore" aparece ladeado, inclusive, por duas facas de inquestionável natureza fálica, em cujas lâminas desponta a letra "B", como marca ou monograma do artista. 
Os temas escatológicos integram o repertório dos artistas desde tempos imemoriais. Alguns, como Bosch, Brueghel e Rogier van der Weyden (1399/1400-1464), os trataram com apelo dramático; outros, como Jan Davidszoon de Heem (1606-1684) e Willem Claesz Heda (1594-1680), apostaram na natureza-morta para sugerir a impermanência; já nomes como Guercino (1591-1666) e Nicolas Poussin (1594-1665) ofereceram suas homônimas Et in Arcadia ego, ${ }^{23}$ de grande carga filosófica, para discorrer sobre a morte. Esse também é o cerne de Os

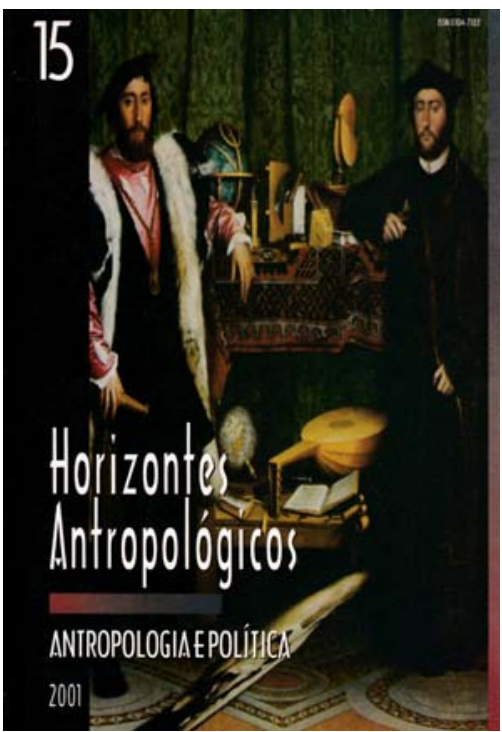
embaixadores franceses (1533), pintura parcialmente reproduzida na capa do número 15 de Horizontes Antropológicos, com temática "Antropologia e política" - em cujo texto de apresentação, curiosamente, não há qualquer referência à escolha de tão invulgar obra.

\section{"Não se vê nada"}

Diante d'Os embaixadores franceses, do alemão Hans Holbein (1497-1543), uma pessoa minimamente acostumada às imagens artísticas será capaz de identificar e associar diferentes aspectos, tais como: (1) a pintura exibe dois homens ricos, vide as roupas luxuosas que portam; (2) esses homens deveriam ser cultos, pois se projetam em meio a vários artefatos relacionados às ciências e às artes; (3) em termos de gênero artístico, trata-se de um retrato e, não apenas isso, de um retrato de corte, justamente devido aos objetos elitizados; (4) e, contrapondo

23 As pinturas de Guercino e de Poussin têm, ambas, o mesmo título: Et in Arcadia ego. Enquanto a do pintor italiano (1618-1622), um óleo sobre tela com $82 \times 91 \mathrm{~cm}$, está na Galleria Nazionale dell'Arte Antica, em Roma, Itália, a de Poussin (1637-1639), também um óleo sobre tela, de $85 \times 121 \mathrm{~cm}$, localiza-se no Musée du Louvre, em Paris. Sobre as obras em questão, ver os textos de Panofsky (1991) e Marin (2000). 
a representação meticulosa da cena, há um elemento dissonante no primeiro plano, que a experiência ou a astúcia velozmente identifica: uma caveira humana, ou melhor, a anamorfose de uma caveira humana. Ah, não menos importante: 0 artista era um mestre da ilusão - e que mestre! Pronto: "imagem decifrada".

O hipotético espectador, nesse momento, pode adotar duas atitudes básicas: a primeira é "seguir em frente", observando múltiplas outras imagens e se surpreendendo com a engenhosidade de tantos artistas, ao longo dos séculos; a segunda é se sentir provocado a elucidar o que aquela caveira está fazendo ali, tão ostensiva, dominando a parte inferior do quadro... A anamorfose sublinha o que Ernst Gombrich tantas vezes aponta: "Somente quando somos confrontados com um tipo totalmente estranho de estrutura é que ficamos cientes do elemento desconcertante que existe em toda representação" (Gombrich, 2012, p. 49). Em toda.

A frase esquadrinha questões caras aos que se dedicam aos estudos sobre imagem e, em especial, aos que se voltam às relações entre imagem e psicologia da percepção, segmento no qual Gombrich foi um expoente. O comentário nos lembra que, antes de se prestar a qualquer tipo de discurso (religioso, político, econômico, filosófico, literário, conceitual...), a imagem é um fenômeno perceptivo, que se dá na relação entre o olho, o objeto de observação e o espaço - leia-se: entre a capacidade de decodificar, o texto e o contexto. A imagem, portanto, inclusive a imagem figurativa de tratamento naturalista, não é um discurso pronto, fechado e unívoco. Dito de outro modo: não basta conseguir ver, é preciso saber olhar, e o ato de olhar, como nos lembra Edmund Husserl, significa dirigir a mente para um "ato de intencionalidade", de significação, que, ainda segundo o filósofo alemão, define a essência do humano.

Na língua portuguesa, as palavras olho e olhar mantêm a mesma matriz e aparentemente remetem à mesma função. Já em outras línguas, a diferença se evidencia. Em espanhol, por exemplo, ojo é o órgão, enquanto o ato de olhar é a mirada. Em francês, oeil é o olho, mas o ato é regarder. Em inglês, eye não está em look. Tampouco em italiano identificamos o liame entre occhio e sguardo; ou, ainda, em alemão, entre Auge e sehen. Essa diversidade não é casual. Para Alfredo Bosi (1988), trata-se de uma percepção, inscrita no corpo dos idiomas, a partir da qual se distingue o órgão receptor externo, ao qual chamamos de olho, do movimento interno do ser que se coloca em busca de informações e de significações, e que é propriamente o olhar. 
Omar Calabrese (1997), em seu ensaio A intertextualidade em pintura - uma leitura dos embaixadores de Holbein, exemplifica esse processo, apresentando-nos um "exercício de olhar". Fazendo jus ao título do livro no qual publica o texto e exibindo a ossatura de seu pensamento, uma base arquitextual em que contrapõe o eidético ao não eidético, o semiólogo italiano nos brinda com uma aula de leitura de imagem, dividindo sua análise em nove estágios.

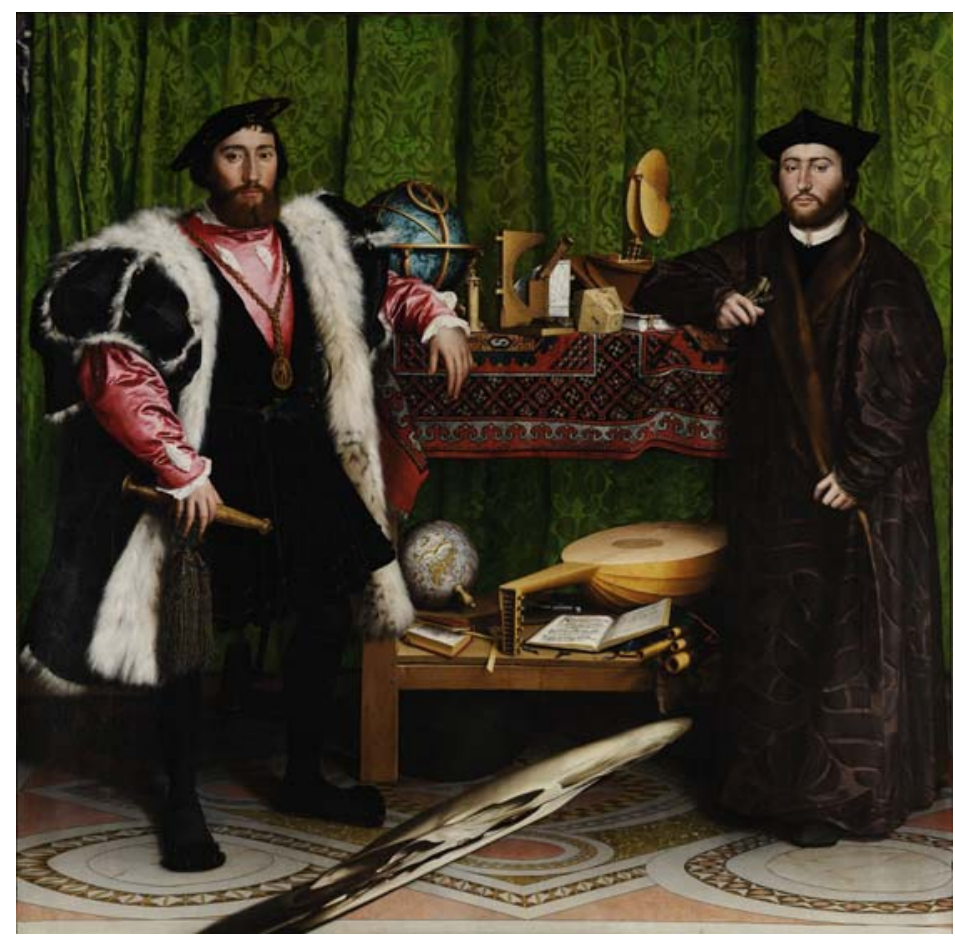

Figura 6. Hans Holbein (1497-1543), Os embaixadores franceses, 1533, óleo sobre madeira, $206 \times 209$ cm, National Gallery, Londres, Inglaterra.

No primeiro, (1) filia Os embaixadores franceses aos Vexierbilder, ou "quadros com segredo". A anamorfose, interpelando o espectador no primeiro plano, obriga-o a encará-la até que este encontre a caveira. Entretanto, a questão não é detectar a "caveira em si", mas compreender o que ela pode significar: eis o 
"segredo". Após, Calabrese (2) nomeia os personagens retratados, o diplomata Jean de Dinteville, à esquerda, e o religioso Georges de Selve, à direita, ambos franceses, em missão político-religiosa junto à corte de Henrique VIII, tentando evitar a ruptura da Inglaterra com a Igreja Católica. É então que, municiado com informações diversas e guiado por um olho inteligente e sensível, ele chega às etapas interpretativas, dissertando a partir dos eixos: (3) cultura, (4) amizade, (5) política, (6) pintura, (7) jogo linguístico, (8) autobiografia e, ao termo, (9) filosofia. Da identificação, nos objetos representados, de alusões a personalidades como Martin Luther (1483-1546), Nicolaus Kratzer (1487-1550), Thomas Morus (1478-1535) e Erasmo de Rotterdam (1466-1536) - os três últimos amigos pessoais de Holbein, retratados por ele -, passando por uma arguta reflexão sobre a morte, verdade que ultrapassa a aparência e o engano da pintura, o que Calabrese defende, de modo exemplar, é que Hans Holbein projetou no aparentemente corriqueiro "retrato de corte" o seu maior testamento artístico, espiritual e filosófico. O mesmo fez o espanhol Diego Rodríguez de Silva y Velázquez (1599-1660) em As meninas (1656), a "Mona Lisa do Prado".

As meninas! Uma vez mais? Não, não e não! Tenham dó! Basta de As meninas! Já se disse tudo sobre elas! [...] Sabemos os nomes e as funções das personagens representadas. Sabemos a sala do palácio onde o quadro foi pintado e o que nele se representa. Identificaram-se até os quadros indistintos que aí vemos: não apenas os que estão de frente para nós, mas também os que vemos de perfil. Em suma: sabe-se tudo e já se disse tudo sobre esse quadro, para o bem e para o mal. Francamente, o que queres tu acrescentar? Deixa o quadro em paz! Deixa-o descansar um pouco. Deixa que as pessoas possam simplesmente apreciá-lo, contemplá-lo. (Arasse, 2014, p. 89).

A galhofa é do historiador da arte Daniel Arasse, na abertura do texto "O olhar do mestre", publicado em seu livro Não se vê nada. Compreensível. Destrinchada por Michel Foucault (1999) no capítulo inicial de seu livro As palavras e as coisas, a pintura é foco contínuo de elucubrações, mormente sobre a relação entre o artista e o espectador e o próprio ato de representar. ${ }^{24} \mathrm{Na}$ obra, Velázquez,

24 Muitos são os artistas que revisitaram a obra, propondo, por meio de suas produções, desdobramentos para os discursos da pintura: Pablo Picasso, entre agosto e dezembro de 1957, produziu 
um dos mestres do mise en abyme (em uma tradução rápida, a "narrativa em abismo"), surge imponente, autorretratando-se em seu ofício. É assim, inclusive, que Foucault inicia seu paradigmático texto: "O pintor está ligeiramente afastado do quadro" (Foucault, 1999, p. 3). Mas, o que Velázquez está tencionando? O que, efetivamente, ele está representando?

As meninas, apesar de sua grande dimensão $(318 \times 276 \mathrm{~cm})$, era um quadro privado, que ficava no "escritório de verão" de Filipe IV (1605-1665), sendo destinado ao seu usufruto; e não era, como muitos pensam, um retrato oficial da infanta Margarita (1651-1673), ainda que rodeada de suas pomposas damas de companhia, que acabaram definindo o nome com que o quadro é conhecido.

Esse, aliás, é um dado pertinente: durante muitos anos, As meninas teve outros títulos: no inventário do Alcázar de 1666, está registrada como Retrato da senhora imperatriz com suas damas e uma anã; depois, como A família do senhor rei Filipe IV, para simplesmente ser chamado de O quadro da família. ${ }^{25} \mathrm{~A}$ "família", aqui, parece entendida como "[...] a família de sangue, com a infanta Margarita que, com o olho esquerdo sobre o eixo central do quadro, observa os pais que vemos refletidos no espelho", e a família alargada, incluindo as aias da infanta e do casal real, representados, em particular, “[...] pelos dois Velázquez: Diego, o pintor, que era também aposentador do rei (uma espécie de marechal do palácio ou camareiro-mor) e José Nieto, aposentador da rainha, que vemos ao fundo da sala, através da porta aberta" (Arasse, 2014, p. 93, grifo do autor). “Dois Velázquez". De certo modo, ao levantar o braço, suspendendo a cortina, a figura ao fundo funciona como uma espécie de metáfora da atividade do pintor, que "dá a ver", "revelando a representação".

a "suíte As meninas", composta por 58 imagens; o brasileiro Waltércio Caldas (1946), em seu livro de artista Velázquez (1996), evidencia o ilegível e o misterioso na poética do artista; a inglesa Eve Sussman (1961), no vídeo As meninas - 89 segundos no Alcázar (2004), reconstrói hipoteticamente o trânsito dos personagens na sala, durante a execução da obra; já o espanhol Manolo Valdés (1942) leva esculturas em bronze às ruas de várias capitais do mundo, emulando as figuras femininas do quadro. E esses são apenas alguns exemplos...

25 A pintura aparece nos registros patrimoniais, com essa designação, até 1843, quando lhe foi dado o nome que mantém nos dias atuais. Sobre as alterações de nome da obra, ver a documentação disponível no sítio virtual do Museo del Prado. 


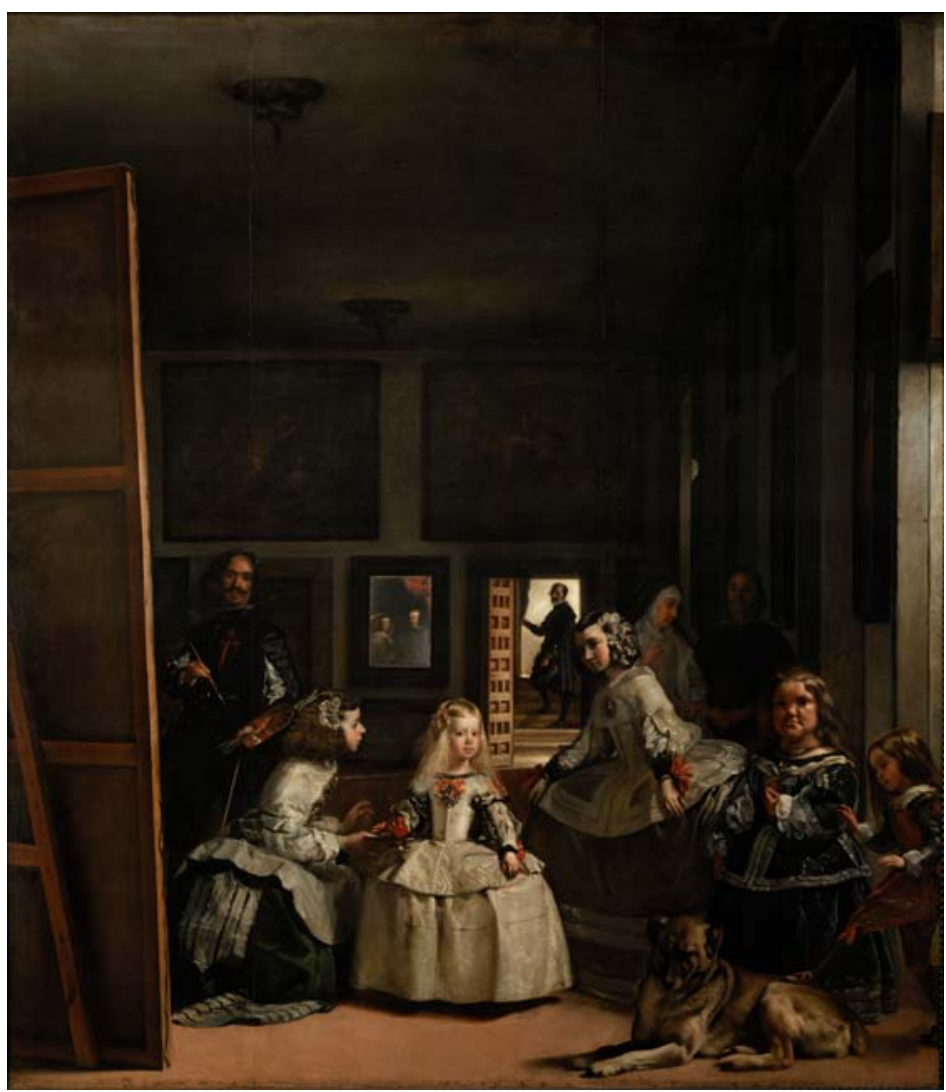

Figura 7. Diego Velázquez (1599-1660), As meninas, 1656, óleo sobre tela, $318 \times 276 \mathrm{~cm}$, Museo del Prado, Madri, Espanha.

Tendo como lugar de encenação uma sala no antigo Real Alcázar de Madri, a pintura intriga sob vários pontos, e um dos principais, sem dúvida, está no espelho. Como assinala Foucault, é pelo reflexo que identificamos o tributo ao rei e à rainha, a homenagem do cortesão Velázquez aos seus patronos. Por outro lado, é essa "presença" fora de nosso alcance de visão que organiza o que vemos. A ficção, portanto, funda a cena, denuncia as condições de representação. ${ }^{26}$

26 Para Daniel Arasse, Velázquez vai mais longe, antecipando Kant em sua Crítica da razão pura (1787). Ao cotejar as posturas do filósofo e do pintor, o ensaísta lembra que Kant, buscando 
A abordagem estruturalista de Foucault, canônica, enfatiza a significação do espelho e o seu reflexo simbólico, bem como a relação entre o visto e o representado, a dialética entre pintura e espectador. Não menos interessante é a interpretação proposta nos anos 1990 pela conservadora do Prado, Manuela Mena Marqués. Após submeter a tela a exames radiográficos, a pesquisadora identificou pequenas manchas brancas sobre as rendas da figura da anã Maria Barbola, bem como vestígios de um anel de ouro, entre o polegar e o indicador da mão esquerda da infanta Margarita, no que seria uma "versão anterior" do quadro. A partir disso, Mena Marqués desenvolveu uma leitura política e dinástica da obra, uma vez que a infanta Margarita seria a herdeira do trono, pelo menos até o nascimento de seu irmão, Filipe, o Próspero (1657-1661). Como se sabe, o quadro, datado de 1656, teve intervenções posteriores, uma delas a inserção, no peitoral do artista, do emblema da Ordem dos Cavaleiros de Santiago, honraria concedida por Filipe IV. Porém, como proclama Mena Marqués, as modificações teriam sido maiores: na primeira versão, segundo ela, nem o pintor, tampouco a tela, estariam presentes. Arasse (2014, p. 93), ao mesmo tempo em que reconhece a pertinência dessa nova mirada, adverte: “[...] não obstante as radiografias, jamais saberemos ao certo como era o quadro antes desses retoques. Se decifrar o que se vê é desde logo uma tarefa delicada, interpretar o que se vê mal, ou não se vê de todo, é como caminhar na corda bamba."

Resultado da primeira ou da segunda versão, não importa: é a autorrepresentação de Velázquez que orienta a retórica da imagem. Então a pergunta esfíngica ressurge: o que está acontecendo ali? Ao que Foucault acena, recuperando o início de seu texto, já citado: "O pintor está ligeiramente afastado do quadro." É quando olhamos, uma vez mais, para a figura altaneira de Velázquez, que suspende o pincel, prestes a conferir realidade, pelas tintas, à pintura em potência que a tela anuncia. Representação no âmago da própria representação... Ao produzir sua obra a partir da consciência do quadro como dispositivo enunciativo, o artista possibilita, como já dissera Hubert Damisch (1997), que a pintura não somente se mostre, mas que revele que "se pensa" e, sobretudo, que dá a pensar.

fundar uma metafísica enquanto ciência, considerava tomar o objeto em dois sentidos, algo que Velázquez também fizera, mas no século anterior: “[...] grande pintor cortesão, 'toma' o rei como fenômeno (no seu grupo familiar) e como 'coisa em si', inatingível no visível. Funda assim, no seu quadro, uma metafísica da realeza” (Arasse, 2014, p. 103). 
"Teologia da pintura", na expressão de Luca Giordano (1634-1705), As meninas exemplifica, de modo sublime, o que Leonardo da Vinci e tantos outros artistas defenderam ao longo dos séculos XIV e XVI, no alvorecer do próprio conceito que temos, hoje, de "arte": longe de simples domínio técnico, arte é, profundamente, cosa mentale. É essa obra emblemática que ilustra, com perspicácia, a capa do número 29 de Horizontes Antropológicos, voltada ao tema "Antropologia e arte". Haveria imagem mais adequada?

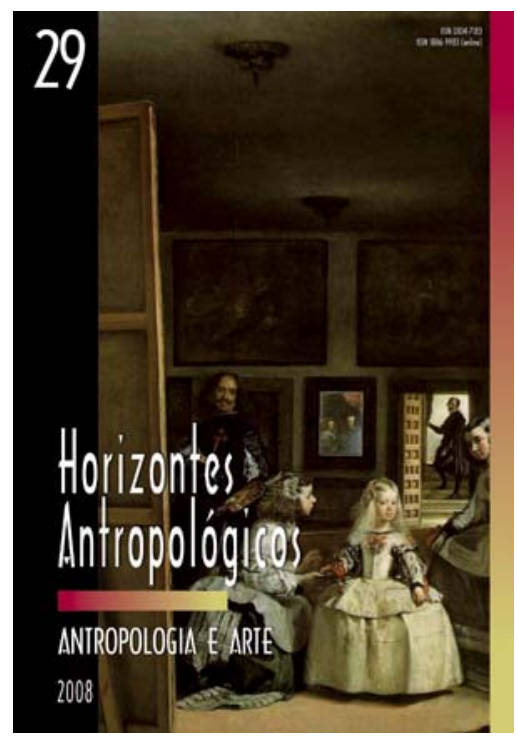

\section{Referências}

ARASSE, D. Não se vê nada. Lisboa: KKYM, 2014.

ARGAN, G. C. Preâmbulo ao estudo da História da Arte. In: ARGAN, G. C.; FAGIOLO, M. Guia de História da Arte. Lisboa: Editorial Estampa, 1994. p. 11-42.

BENJAMIN, W. A obra de arte na era de sua reprodutibilidade técnica. In: BENJAMIN, W. Magia e técnica, arte e política: ensaios sobre literatura e história da cultura. 3. ed. São Paulo: Brasiliense, 1987. p. 165-196. (Obras escolhidas, vol. 1).

BERGER, J. Modos de ver. Rio de Janeiro: Rocco, 1999.

BOSI, A. Fenomenologia do olhar. In: NOVAES, A. (Org.). O olhar. São Paulo: Companhia das Letras: Funarte, 1988. p. 65-87.

BOSING, W. Bosch: entre o céu e o inferno. Colônia: Taschen, 2010.

CALABRESE, O. Como se lê uma obra de arte. Lisboa: Edições 70, 1997.

CATTANI, I. B. Arte moderna no Brasil. Belo Horizonte: Editora C/Arte, 2011.

DAMISCH, H. El origen de la perspectiva. Madrid: Alianza Forma, 1997.

DELEUZE, G. A imagem-tempo. São Paulo: Brasiliense, 2007. 
ECKERT, C.; STEIL, C. A. Apresentação. Horizontes Antropológicos, Porto Alegre, ano 16, n. 34, p. 9-15, jul./dez. 2010. Disponível em: <http://www.scielo.br/pdf/ha/v16n34/01. pdf $>$. Acesso em: 30 jan. 2017.

FOUCAULT, M. As palavras e as coisas. São Paulo: Martins Fontes, 1999.

FREUD, S. Leonardo da Vinci e uma lembrança de sua infância. Rio de Janeiro: Imago, 2001.

GOMBRICH, E. H. The earliest description of Bosch's Garden of Delight. Journal of the Warburg and Courtauld Institutes, v. 30, 1967, p. 403-406. Disponível em: <http:// www.jstor.org/stable/750758>. Acesso em: 30 jan. 2017.

GOMBRICH, E. H. The visual image. Scientific American, New York, v. 227, n. 3, p. 82-96, 1972.

GOMBRICH, E. H. A imagem visual: seu lugar na comunicação. In: WOODFIELD, R. (Org.). Gombrich essencial: textos selecionados sobre arte e cultura. Porto Alegre: Bookman, 2012. p. 41-64.

GOMIDE, A. C. Colecionismo de arte moderna e contemporânea no Brasil: um estudo. 2014. Tese (Doutorado em Artes)-Escola de Belas Artes, Universidade Federal de Minas Gerais, Belo Horizonte, 2014.

GOTLIB, N. B. Tarsila do Amaral: a modernista. São Paulo: Editora Senac, 1998.

JANSON, H. W. A nova História da Arte de Janson: a tradição ocidental. Lisboa: Fundação Calouste Gulbenkian, 2010.

KOLDEWEIJ, J.; VANDENBROECK, P.; VERMET, B. Hieronymus Bosch: the complete paintings and drawings. New York: Abrams, 2001.

MARIN, L. Panofsky e Poussin na Arcádia. In: MARIN, L. Sublime Poussin. São Paulo: Edusp, 2000. p. 97-119.

NABAIS, J.-M. Rembrandt - o quadro "A lição de anatomia do Dr. Tulp" e a sua busca incessante pelo autoconhecimento. Revista da Faculdade de Letras: Ciências e Técnicas do Património, Porto, v. 7-8, p. 279-296, 2008-2009. Disponível em: <http://ler. letras.up.pt/uploads/ficheiros/9417.pdf>. Acesso em: 30 jan. 2017.

OLIVEN, R. G.; PINHEIRO-MACHADO, R. Apresentação. Horizontes Antropológicos, Porto Alegre, ano 13, n. 28, p. 7-13, jul./dez. 2007. Disponível em: <http://www.scielo. br/pdf/ha/v13n28/a01v1328.pdf>. Acesso em: 30 jan. 2017.

PANOFSKY, E. Et in Arcadia ego: Poussin e a tradição elegíaca. In: PANOFSKY, E. Significado nas artes visuais. São Paulo: Perspectiva, 1991. p. 377-409. 
ROHDEN, F.; RUSSO, J. A.; ROCA, A. Apresentação. Horizontes Antropológicos, Porto Alegre, ano 23, n. 47, p. 9-24, jan./abr. 2017. Disponível em: <http://www.scielo.br/pdf/ ha/v23n47/0104-7183-ha-23-47-0009.pdf>. Acesso em: 30 mar. 2017.

SCHAMA, S. O poder da arte. São Paulo: Companhia das Letras, 2010.

WARBURG, A. A renovação da antiguidade pagã: contribuições científico-culturais para a história do Renascimento europeu. Rio de Janeiro: Contraponto, 2013.

Recebido: 01/02/2017 Aceito: 08/08/2017 | Received: 2/1/2017 Accepted: 8/8/2017 